National Air Force University. No. 2. pp. 207-212. [in Ukrainian].

7. Skubashevska, O.S. (2016). Masova vidkryta onlain osvita yak mozhlyvist navchannia protiahom zhyttia [Mass online education as an opportunity for lifelong learning]. Scientific Journal of KhNPU. Philosophy series. No.46. pp. 140-150. [in Ukrainian].

8. Segol, R. (2020). Universytet maibutnoho: Onlain-osvita ta zmishane navchannia [University of the Future: Online Education and Blended Learning]. Available at: https://www.youtube.com/watch?v=b1-
p-3_Q-5I (Accessed 10 Nov. 2020). [in Ukrainian].

9. Segol, R. (2020). Yak navchatys onlain i nichoho ne vpustyty [How to study online and miss nothing]. Available at: https://www.youtube.com/ watch? $v=$ EAEnKlss6yo (Accessed 10 Nov. 2020). [in Ukrainian].

10. Tkach, T.V. (2010). Psykholohichni zasady proektuvannia osvitnoho prostoru osobystosti [Psychological principles of designing the educational space of the individual]. Extended abstract of Doctor's thesis. Kyiv, 50 p. [in Ukrainian].

Стаття надійшла до редакції 10.08.2021

УДК 373.2.015.31:7

DOI:

Надія Дудник, кандидат педагогічних наук, доцент кафедри загальної педагогіки та дошкільної освіти Дрогобицького державного педагогічного університету імені Івана Франка

\title{
ПЕДАГОГІЧНІ НОВАЦІЇ В ЕСТЕТИЧНОМУ ВИХОВАННІ ДІТЕЙ СТАРШОГО ДОШКІЛЬНОГО ВІКУ
}

У статті розкривається сутність таких понять, як естетика, естетичне виховання, народознавча культура, сенсорне виховання. Основна увага відведена виокремленню проблеми необхідності зосередження уваги педагогів на естетичному вихованні дітей раннього та дошкільного віку в умовах ЗДО. Проаналізовано дослідження сучасних науковців щуодо особливостей впливу естетичної культури на загальний розвиток дитини. Подано для обговорення проблему виховання дітей дошкільного віку з позиції формування естетичної культури та знань й умінь у народознавчій сфері. Виокремлено проблему професійного саморозвитку педагогів ЗДО у естетичному розвитку через участь у творчих майстер-класах, художньо-естетичних заходах, практичній демонстрації своїх талантів у процесі організації освітнього процесу з дошкільниками як на спеціальних заняттях, так і в опосередкованих вправах, де вміння поєднувати знання і вміння у мистецькій галузі мають місие у життєдіяльності вихованців. Подано перспективу педагогічного впливу на процес естетичного виховання з використанням альтернативних, авторських мистецьких програм, які сприяють творчому розвитку педагогів, дошкільників та батьків вихованців.

Ключові слова: естетичне виховання; народознавче виховання; творчий розвиток; сенсорне виховання; мистецтво; діти дошкільного віку.

Jim. 10.

Nadiya Dudnyk, Ph.D.(Pedagogy), Associate Professor of the General Pedagogy and Preschool Education Department Drohobych Ivan Franko State Pedagogical University

\section{PEDAGOGICAL INNOVATIONS IN AESTHETIC EDUCATION OF PRESCHOOL CHILDREN}

The article reveals the essence of such concepts as aesthetics, aesthetic education, ethnographic culture, sensory education. The main attention is paid to highlighting the problem of the need to focus pedagogues on the aesthetic education of children of early and preschool age in the conditions of PEI. The research of modern scientists on the peculiarities of the influence of aesthetic culture on the general development of the child is analyzed. The problem of educating preschool children from the standpoint of the formation of aesthetic culture and knowledge and skills in the field of ethnography is presented for discussion. The aim of the article is to find ways to combine the achievements of technical and informational progress with the need to practically involve children in the development of knowledge of the art of music, art, dance, poetry, theater, which has a cultural content and national characteristics. The problem of professional self-development of PEI pedagogues in aesthetic development through participation in creative master classes, artistic and aesthetic events, practical demonstration of their talents in the process of organizing the educational process with preschoolers both in special classes and in indirect exercises, where the 
ability to combine knowledge and skills in the field of art take place in the lives of students. The perspective of pedagogical influence on the process of aesthetic education with the use of alternative, author's art programs, which promote the creative development of teachers, preschoolers and parents of pupils, is given.

Keywords: aesthetic education; ethnographic education; creative development; sensory education; art; preschool children.

П остановка проблеми у загальному вигляді. В організації освітнього процесу для гармонійного розвитку особистості важливо урівноважувати розумове, валеологічне, культурологічне, соціальне виховання. Щодо культурологічного виховання, то завданнями $є$ поступове прилучення дитини до світу краси, естетики, мистецтва. 3 дошкільного віку, коли відчуття та смаки формуються, дитину необхідно знайомити з мистецькими надбаннями людства, задіювати у культурних народознавчих заходах, збагачувати духовну сферу і пояснювати зміст традицій.

Одна із ліній розвитку дитини раннього та дошкільного віку нової редакції базового компонента дошкільної освіти є “Культура" передбачає: “Формування наскрізних умінь в дитини, що забезпечує наступність між дошкільною та початковою освітою” і ставить завданням виховання “елементарної обізнаності дитини в різних видах мистецтва” $[1,4]$. Адже мистецтво $є$ і засобом розвитку дитини у народознавчому змісті культури та традицій рідного народу, знайомить зі світовими шедеврами, і способом естетичного розвитку емоційної, відчуттів у вихованні моральних цінностей. Твори мистецтва сприяють удосконаленню розумової діяльності, активізуючи сприймання, аналітичне мислення, творчість. Музика, танці, художні твори розвивають сенсорні відчуття, збагачуючи дитину знаннями про особливості, естетичну привабливість навколишнього світу.

Аналіз останніх досліджень і публікацій. Особистість як суб'єкт у процесі розвитку на основі впливу культурних цінностей досліджували Є. Ільєнков, В. Біблер, В. Давидов та ін.; з позиції ознайомлення з загальнокультурними традиціями спілкування, виховання моральності як досвід взаємин попередніх поколінь представлений у працях В. Петровського, О. Запорожця, Н. Лисенко та ін.; акцент на особистісний розвиток творчих задатків, самопізнання, саморозвитку на основі практичного доручення до мистецтва роблять вчені Н. Поддьяков, І. Ликова, Л. Сакуліна, Л. Назарук, Л. Калузька та ін. В оновленому Базовому компоненті дошкільної освіти акцентується увага на формуванні дитячої компетентності у мистецькій сфері за умови “закріплення академічної свободи педагогічних працівників, зміна філософії контролю якості освіти та методологію підтримки, запровадження альтернативних інституційних форм здобуття дошкільної освіти" $[10,2]$. Науковці приходять до висновку що незаперечну цінність мистецтва, яке є учителем дитини у світорозумінні, визначенні балансу красивого та корисного, формуванні змісту, методів реалізації знань, набутті умінь творити, робити життя прекрасним, насолоджуватися звуками, барвами, формами.

Виділення невирішених раніше частин загальної проблеми. Природна потреба збереження балансу у духовному, культурному, народознавчому напрямі актуалізують проблему естетичного виховання дітей 3 використанням новацій в інформаційних технологіях освіти, а також прилучення педагогів, батьків вихованців та дітей до рукотворних культурних цінностей людства. Тому заняття музикою, малюванням, танцями, ознайомлення 3 народознавчими традиціями у ткацтві, гончарстві, вишивці стають необхідними умовами всебічного розвитку дитини у гармонії зі світом краси, активізації пізнавального інтересу до усвідомлення національної ідентичності та уможливлення спробувати власні сили у творчості.

Незаперечним $є$ твердження, що мистецтво займає важливе місце у процесі формування особистісно-ціннісного ставлення дошкільників до культурної спадщини людства. Адже перший досвід освітньої та естетичної діяльності залишає враження на все життя, а дошкільний вік є найбільш сприйнятливий до краси, діти сповнені бажанням змінювати світ на краще, самостійно створювати нове.

Загальна освіта передбачає часткове ознайомлення дітей 3 мистецькими творами, а не оволодіння знаннями та вміннями їх створювати, використовувати у життєдіяльності.

Метою статті $\epsilon$ виокремлення культурологічних та виховних цінностей естетичного виховання у загальному розвитку особистості, а також наголошення на важливості виховання народознавчої культури у період дошкільного дитинства.

Виклад основного матеріалу. У процесі цілеспрямованого виховного впливу на спеціальних заняттях музики, співу, танцю, збагачуються знання про красу, гармонію звуків, барв, пластичність рухів. Наслідуючи, дитина вивчає можливості свого тіла, практикує з відчуттями, 


\section{ПЕДАГОГІЧНІ НОВАЦЇ̈ В ЕСТЕТИЧНОМУ ВИХОВАННІ ДІТЕЙ СТАРШОГО ДОШКІЛЬНОГО ВІКУ}

емоціями, вчиться бачити і творити прекрасне. Згодом культурологічна інформація набуває осмисленості, на основі активізації сенсорних відчуттів стають довільними вміння у використанні та координації рухів, сприйняття естетики набувають ціннісного змісту.

Одним із важливих напрямів гармонійного розвитку людини в освітній діяльності $€$ формування “здатності реалізувати на практиці свій художньо-естетичний потенціал для одержання власного неповторного результату творчої діяльності з пріоритетом розвитку почуттєвої сфери особистості у спрямованні на формування життєвої компетентності під час освітньої та самостійної художньої діяльності” [ $[$, 8]. Розв'язання такого завдання вимагає спеціальної підготовки педагога в організації освітнього простору, створенні умов для активізації пізнавальної діяльності дітей, володіння інноваційними способами ознайомлення вихованців 3 культурною спадщиною людства задля активізації внутрішньої мотивації дітей до розвитку, самовираження, творчої діяльності.

В умовах особистісно розвивальної концепції важливими є гуманістичні умови співпраці педагогів та вихованців, які забезпечують суб'єктивність становлення творчої особистості, а педагогу дають простір для презентації культурних знань, залишають місце у способах інтерпретації культурологічних знань, застосування авторських програм, авангардних технологій, нетрадиційних методик малювання, поєднання танцювального мистецтва з аеробікою, спортивною гімнастикою тощо. Під час участі у майстер-класах, творчих майстернях, конференціях педагог розширює власні знання, розвиває здібності, вчиться гармонії світовідчуття, випробовує себе як сміливий самостійний діяч у мистецькій діяльності. Адже тільки активна, творча людина може пояснити красу та вишуканість естетики, створити атмосферу творчості у діяльності з вихованцями.

Актуальність розгляду теми естетичного розвитку вважаємо доцільним у світі швидкоплинного технологічного й інформативно прогресу, коли мистецькі твори стають як більш доступними у віртуальному знайомстві, так і займають щоразу менше місця у використанні сучасної людини, яка все рідше особисто відвідує мистецькі виставки, що збіднює емоційні відчуття. Урівноваження та гармонія чуттєвої сфери у процесі культурологічного розвитку особистості та розумне використання технологій стають актуальними освітніми завданнями, які розв'язують педагоги у роботі з дітьми, починаючи з дошкільного віку.

Історія розвитку людства вражає бережливим ставленням наших предків до краси навколишнього світу, а потреба оздоблювати побутові речі, предмети вжитку набувають характерних ознак, стають предметом для вивчення культурологів. Потреба гармонії кольорів, звуків, грації рухів, співзвучність природи панувала в культурі українців і збереглася в археологічних та мистецьких пам'ятках з часів трипільської доби. Наші предки у створенні житла залишали місце для духовного розвитку, естетично оздоблювали приміщення, прикрашали кольоровими рисунками посуд, жінки носили намисто, вишивали й гаптували одяг. Потреба краси, естетики притаманна тільки людині, їй доступне відчуття захоплення, радісного піднесення від споглядання чи слухання гармонії барв та звуків, форм і рухів. Така природна потреба у наповненні життя естетичними формами, звуками для милування зумовила розвиток мистецтва.

3 раннього дитинства людина спостерігає, порівнює, пізнає, вивчає світ на рівні сенсорного сприймання, яке стає основою розумового, культурологічного розвитку. В дошкільному віці $є$ загострена емоційна чутливість до сприймання художніх образів у літературі, образотворчому мистецтві, музиці, адже все нове вражає, формує смак, свідомість дитини, знаходить відгук у почуттях. За визначенням відомої педагогині М. Монтессорі: “Дитина володіє іншою формою розуму, відмінною від розуму дорослого, що має властивість вбирати. Особливість у тому, що так, як і губка вбирає будь-яку воду - чисту чи брудну, прозору чи каламутну або підфарбовану, дитячий розум абсорбує образи зовнішнього світу, не поділяючи їх на “добрі” i “погані”, “корисні” “марні” [6, 20]. Т. Поніманська пише що естетичне виховання - “це послідовне формування у дітей естетичного ставлення до життя, розвиток сприймання і розуміння прекрасного в мистецтві, природі, взаєминах людей, художніх потреб і здатності до художньої творчості" [8, 110]. Вважаємо, що важливим стає завдання педагогів та батьків створювати естетично гармонійний освітній простір, наповнювати життя дитини виробами народного ремесла, що мають як культурологічну цінність, так і духовну, виховну. Адже створена 3 естетичним смаком руками людини вишивка, посуд, іграшка, предмет побуту мають позитивну енергетику, демонструють можливості людини як творця. Досліджуючи, вивчаючи такі предмети, дитина вчиться бачити прекрасне, зчитувати інформацію творця 3 предметів мистецтва, 


\section{ПЕДАГОГІЧНІ НОВАЦЇ̈ В ЕСТЕТИЧНОМУ ВИХОВАННІ ДІТЕЙ СТАРШОГО ДОШКІЛЬНОГО ВІКУ}

бережливо ставитися до мистецтва, розуміти його.

Чуттєвий світ дитини є першою сходинкою у пізнанні світу прекрасного. Дорослий повинен відчути й зрозуміти прагнення малюка до пізнання та отримання інформації про предмет на дотик, смак, нюх, а також надати вербальні знання про назву та продемонструвати призначення предмета, емоційно виразити ставлення до нього, захоплення красою. Такі естетичні прийоми ознайомлення дитини з мистецтвом переплітаються у гармонії з практичним їх застосуванням, емоційно позитивним враженням. Предмети культури стають необхідністю буття, набувають змісту у використанні. Поєднання високоестетичного та практичного в предметах та мистецьких творах створюють гармонію людського буття, в якому визначним є естетичний смак, формується культура. Отже, особистість - це суб'єкт сприймання і творення естетичних цінностей як форм культури (Є. Ільєнков, В. Біблер, В. Давидов), загального й значущого для інших людей, в яких він ідеально представлений (В. Петровський, Т. Поніманська, О. Запорожець), й одночасно суб'єкт самопізнання, саморозвитку, самотворення (Н. Поддьяков, Н. Лисенко, І. Ликова). Дошкільник зростає в атмосфері традицій, праці, естетики, творчості, а досягнення прогресу стають засобами раціональної комунікації, урізноманітнюють можливості мистецьких занять.

У Концепції українського національного виховання акцентується увага на “необхідності пізнання перлин національного мистецтва, на значенні висвітлення правдивої історії культури й освіти суспільства, повернення до культурних надбань" [3, 6]. Для розв'язання завдань естетичного характеру в процесі підготовки вихователів у вищій школі звернено увагу на способи розвитку естетичного смаку майбутніх педагогів, прилучення до світу краси та мистецтва, розвиток народознавчої культури. Народознавчій роботі у підготовці педагогів до діяльності в ЗДО студентів приділено велику увагу; зокрема у формуванні знань 3 основ народознавства, естетики, декоративного мистецтва, рідної літератури, народного декоративно-ужиткового мистецтва, музики, танців.

Потреба людини у милуванні та створенні прекрасного, необхідність збереження культурних цінностей обумовлюють необхідність естетичного виховання, а виокремлення завдань культурологічного змісту $з$ раннього дитинства сприяють розвитку естетичного світобачення. Л. Назарук пише: “В естетичному розвитку дошкільників центральною є здатність до сприймання художніх образів та самостійного їх створення... Ці показники стосуються як кінцевого продукту, так і способу та характеру процесу діяльності, з урахуванням індивідуальних особливостей та можливостей дітей” $[7,10] .3$ раннього дитинства педагоги та батьки повинні здійснювати естетичне виховання засобами споглядання краси природи, гармонії кольору практичності і вишуканості предметів побуту, включення в інтер'єр та життєдіяльність мистецьких творів, які вчать дітей милуватися природою, споглядати художні образи, слухати музичні твори, розвивають смак, відчуття, розумові здібності.

Неабияке значення має створення можливостей для прилучення дітей до різноманітних видів художньої діяльності, що дасть їм змогу розширити діапазон естетичного пізнання світу, спробувати свої сили у різних сферах, зосередитися на найпривабливішій і найперспективнішій для себе. Найчастіше у закладах дошкільного виховання дітей прилучають до таких видів художньої діяльності: “Зображувальна діяльність (сприймання творів образотворчого мистецтва, малювання, ліплення, виготовлення аплікацій); музична діяльність (сприйняття музики, співи, ігри, танці, хороводи, гра на музичних інструментах); художньомовленнєва діяльність (слухання казок, розповідей, читання віршів, творчі розповіді тощо); театралізована діяльність" $[2,12]$. Як зазначає I. Ликова: “розвивальна освіта - це особлива педагогічна система та форма особистісного співбуття дітей та дорослих" [5, 37]. Ефект проблематизації повсякденного досвіду підсилюється завдяки розвивальному потенціалу образів як способу розвитку інтерверсійного (на рівні уяви) мислення.

У сучасному світі $€$ потреба глибинного осмислення, коригування педагогічної теорії і практики естетичного виховання, де буде поєднано досягнення цивілізації (можливості комп'ютерних технологій) та досліджень науковців у способах поступального розвитку дитини на основі сенсорики, формування естетичної культури на засадах народознавчих традицій, знайомства 3 досягненнями людства у світі краси. Слід так спрямувати виховання, щоб цінності класичної культури не були знищені комп'ютерною цивілізацією, нестримним темпом технологізації світу. У нових явищах нашого життя гармонійний розвиток дитини можливий лише за умов повноцінного естетичного виховання, яке на практиці знайомить дитину з мистецькими творами рідної культури, долучає до застосування 
вмінь та саморозвитку, творчих проявах у процесі виховання в умовах ЗДО. Предмети народної культури стають окрасою та засобами культурного виховання, вчать працьовитості, наполегливості, формують знання і вміння самостійно творити.

Естетичне виховання передбачає перетворення відчуттів на слова, дії, створює сенсорні еталони, необхідні для формування емоційних оцінок, знання про види і жанри мистецтва, особливості їх виражальних засобів, про діячів мистецтва (художників, музикантів), а також можливість у вербальній формі опредметнити відчуття, 3'ясувати сутність естетичних оцінок (гарне, негарне, потворне, смішне, сумне).

Аналізуючи етапи становлення естетичної культури, виокремимо два напрями: естетичне сприймання формується у спогляданні природи, кольорів, відтінків, прослуховуванні музичних творів, пісень і $€$ початковим; естетичне ставлення до дійсності формується під час екскурсій, споглядання, спостереження за красою природи, витворами мистецтва, коли дитина здійснює вибір. Такий поступальний розвиток мислення, відчуттів, самостійної діяльності у сфері естетики та культури набуває особистісного ставлення, знаходить відгук, формує уподобання.

Позаяк візуальне сприймання є важливим, то Р. Штайнер, М. Монтессорі зауважували про необхідність твору високого мистецтва у приміщенні, де перебувають діти, зокрема, зображення матері і дитини, які представлені у високохудожніх полотнах Рафаеля "Мадонна 3 немовлям", Брюге “Мадонна 3 Христомнемовлям”, Мікеланжело “Мадонна $з$ немовлям”. Репродукції таких полотен служать як естетичною прикрасою, так і виконують виховну функцію у формуванні поваги до материнства. Діти дошкільного віку завдяки емоційній чутливості мають змогу долучитися до світу прекрасного, яке гармонізує співіснування близьких людей.

Педагоги під час спеціально організованих мистецьких занять та в опосередкованих бесідах на теми естетичної культури знайомлять дітей 3 еталонами краси, розвивають аналітичне мислення, вміння бачити прекрасне, бажання творити і вдосконалювати світ довкола себе. Заняття, які включають народознавчі теми долучають дитину до цінностей культури свого народу, виховують патріотизм, повагу до національних традицій, символіки.

Висновки. Естетичне виховання стає однією зі складових загальнокультурного розвитку особистості, способом прояву власного внутрішнього розуміння світу, бачення красивого, бажання творити і милуватися прекрасним. У вихованні дошкільників важливе місце посідає їх прилучення до народної культури, формування патріотичних почуттів, поєднання народних традицій в естетичній культурі.

Діти за своєю природою наслідують дії дорослих, тому в освітньому процесі поруч повинен бути обізнаний педагог, який створює умови творчого розвитку, заохочує дітей до різноманітних видів художньої діяльності, що дасть їм змогу реалізувати прагнення до естетичного пізнання світу, спробувати свої сили у мистецтві. Педагоги стають провідниками та носіями норм моралі, культури, естетики, першими авторитетними дорослими, які моделюють світ прекрасного, тому, їм потрібно вдосконалювати свої творчі здібності, розширювати культурологічні знання.

У період дошкільного виховання важливо забезпечити своєчасний розвиток чутливості сенсорного апарату дитини, сформувати емоційний відгук на сприймання найяскравіших якостей і властивостей предметів та явищ мистецтва. Важлива виховна складова художньої діяльності дитини, коли формуються цілі і шляхи ix досягнення, у практичній діяльності розвивається цілеспрямованість, зосередженість, взаєморозуміння, єднання дітей у спільних переживаннях і діях. За своїм змістом естетична діяльність повинна містити народознавчий характер, що виховує громадянські чесноти, національну ідентичність.

\section{ЛІТЕРАТУРА}

1. Базовий компонент дошкільної освіти / Науковий керівник: А. М. Богуш, дійсний член НАПН України, проф, д-р пед. наук та ін. Київ: Видавництво, 2012.26 с.

2. Бріалко Т.Б. Особливості мислення старших дошкільників. Харків: “Ранок”, 2010. 160 с.

3. Концепція Нової української школи /за заг.ред. Лілії Гриневич, 2016. 34 с. https:// www.google.com/search?

4. Лисенко Н.В., Крутій Н.Р. Педагогіка українського довкілля: навч. посіб. Київ: Вища школа, 2006. Ч.1. 302 с.

5. Ликова І.О. Програма художнього виховання, навчання і розвитку дітей $2-6$ років. Харків: "Ранок", 2008. $128 \mathrm{c}$

6. Монтессорі М. Всотуючий розум. М. Монтессорі: теорія і технологія. Видавничий Дім “Слово”, 2009. C. $19-24$.

7. Назарук Л.М. Формування етноестетичних цінностей дітей дошкільного та молодшого 
шкільного віку засобами українського народного мистецтва : навч.-метод. посіб. Львів, 2014. 120с.

8. Поніманська T.I. Дошкільна педагогіка: підручник. Київ: Академвидав, 2006. 456 с.

9. Програма розвитку дитини дошкільного віку "Українське дошкілля" / О.І. Білан, Л. М. Возна, О.Л. Максименко та ін.. Тернопіль: Мандрівець, 2018. 264 c.

10.Шкарлет С. Система раннього розвитку дитини має базуватися на принципах якості, наступності та доступності / Виступ 3 червня 2021 p. на Всеукраїнському форумі "Україна 3О. Освіта і наука"/ https://mon.gov.ua/ua/news/sergij-shkarletsistema-rannogo-rozvitku-ditini-maye-bazuvatisyana-principah-yakosti-dostupnosti-ta-nastupnosti

\section{REFERENCES}

1. Bazovyy komponent doshkilnoyi osvity (2012). [Basic component of preschool education]. Supervisor: A. M. Bohush, a member of the NAPS of Ukraine, Prof. Dr. Ped. sciences, etc. Kyiv, 26 p. [in Ukrainian].

2. Brialko, T.B. (2010).Osoblyvosti myslennya starshykh doshkilnykiv [Features of thinking of senior preschoolers]. Kharkiv, 160 p. [in Ukrainian].

3. Kontseptsiya Novoyi ukrayinskoyi shkoly (2016). [The concept of the New Ukrainian school]. (Ed.). Liliyi Hrynevych, 34 p. Available at: https:// www.google.com/search? [in Ukrainian].

4. Lysenko, N.V. \& Krutiy, N.R. (2006). Pedahohika ukrayinskoho dovkillya: navch. posib. [Pedagogy of the Ukrainian environment]. Kyiv, part.1. 302 p. [in Ukrainian].
5. Lykova, I.O. (2008). Prohrama khudozhnoho vykhovannya, navchannya i rozvytku ditey $2-6$ rokiv [The program of art education, training and development of children $2-6$ years]. Kharkiv, $128 \mathrm{p}$. [in Ukrainian].

6. Montessori, M. (2009). Vsotuyuchyy rozum [Absorbing mind]. M. Montessori: theory and technology.pp. 19-24. [in Ukrainian].

7. Nazaruk, L.M. (2014). Formuvannya etnoestetychnykh tsinnostey ditey doshkilnoho ta molodshoho shkilnoho viku zasobamy ukrayins№koho narodnoho mystetstva [Formation of ethno-aesthetic values of children of preschool and primary school age by means of Ukrainian folk art]. Lviv, 120 p. [in Ukrainian].

8. Ponimanska, T.I. (2006). Doshkilna pedahohika [Preschool pedagogy]. Kyiv, 456 p. [in Ukrainian].

9. Prohrama rozvytku dytyny doshkilnoho viku "Ukrayinske doshkillya"(2018). [Program of preschool child development "Ukrainian preschool"]. O.I. Bilan, L. M. Vozna, O.L. Maksymenko et al. Ternopil, 264 p. [in Ukrainian].

10. Shkarlet, S. Systema rannoho rozvytku dytyny maye bazuvatysya na pryntsypakh yakosti, nastupnosti ta dostupnosti [The system of early child development should be based on the principles of quality, continuity and accessibility]. Speech June 3, 2021 at the All-Ukrainian Forum "Ukraine 30. Education and Science". Available at: https:// mon.gov.ua/ua/news/sergij-shkarlet-sistemarannogo-rozvitku-ditini-maye-bazuvatisya-naprincipah-yakosti-dostupnosti-ta-nastupnosti [in Ukrainian].

Стаття надійшла до редакції 12.07.2021

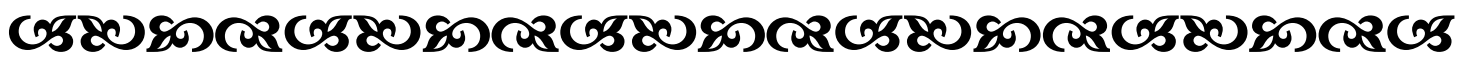

"Навчання й досі розуміють лише якрозвитокрозуму, в той час коли воно має стати джерелом сил для оновлення та творення".

“Виховання має сқеровувати діяльність, а не пригнічувати ї̈. Завдання педагога в тому, щоб насичувати та сприяти, спостерігати, заохочувати, спонуқати, а не втручатися, нақазувати чи обмежувати".

$$
\begin{array}{r}
\text { Марія Монтессорі } \\
\text { італійський педагог, лікар, ббілособб }
\end{array}
$$

"Жобоб виховати людину висоқого інтелекту, қрасиву й багату емоиіонально, вчитель не може обійтися без книги, без иілого світу художніх образів. Книга - велика сила, ие правда, але в руқах доброго вчителя, ми знаєм, ия сила подвоюється. Слава тому вчителеві, яқий на все життя прищеплюе юному серию любов до художнього твору, до його правди, до його қраси".

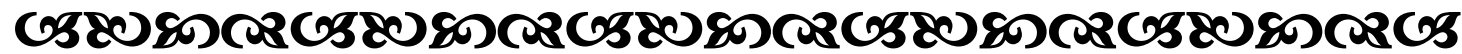

